\title{
AKUNTABILITAS KINERJA PEMERINTAH DAERAH DALAM PENYELENGGARAAN PELAYANAN PUBLIK DI KABUPATEN LABUHANBATU SELATAN
}

\author{
Wildan Aswan Tanjung ${ }^{1}$, Sampara Lukman ${ }^{2}$, Khasan Efendy ${ }^{3}$, Aries Djaenuri ${ }^{4}$ \\ ${ }^{1,2,3,4}$ Institut Pemerintahan Dalam Negeri (IPDN) \\ Email:wildan.at@gmail.com
}

\begin{abstract}
Abstrak
Penelitian ini menggambarkan akuntabilitas kinerja pemerintah daerah dalam penyelenggaraan pelayanan publik di Kabupaten Labuhanbatu Selatan yang meliputi akuntabilitas kejujuran dan hokum, akuntabilitas proses, dan akuntabilitas keuangan dan program. Metode yang digunakan dalam penelitian ini adalah metode penelitian deskriptif dengan melakukan survey dan wawancara. Penelitian menemukan bahwa masih belum terfokusnya perizinan dalam satu tempat, prosedur perizinan yang masih memerlukan tanda tangan manual, koordinasi internal dan eksternal yang masih manual dan kurangnya pemahaman dari masyarakat merupakan penghambat dalam kinerja penyelenggaraan pelayanan publik.
\end{abstract}

Kata Kunci: Akuntabilitas, Kinerja, Pelayanan Publik.

\begin{abstract}
This study illustrates the accountability of local government performance in the administration of public services in South Labuhanbatu Regency which includes honesty and legal accountability, process accountability, and financial accountability and programs. The method used in this research is descriptive research method by conducting surveys and interviews. The study found that licensing is still not focused in one place, licensing procedures that still require manual signatures, internal and external coordination are still manual and the lack of understanding from the community is an obstacle in the performance of public service delivery.
\end{abstract}

Keywords: Accountability, Performance, Public Service.

\section{A. PENDAHULUAN}

Harapan rakyat Indonesia pada umumnya di Kabupaten Labuhanbatu Selatan pada khususnya adalah terwujudnya penyelenggaraan pemerintahan dengan kinerja pelayanan yang berkualitas yang dapat dipertanggungjawabkan; (pelayanan yang lahir dari hati, dilaksanakan dengan setulus hati, serta hati-hati) dapat dijadikan sebagai bukti, bahwa negara hadir untuk melayani rakyatnya.

Perlu diketahui bahwa Kabupaten Labuhanbatu Selatan dengan jumlah penduduk cukup padat, yang memiliki luas wilayah yang sangat luas dengan potensi alam memadai membutuhkan 
kehadiran Negara untuk memenuhi harapan hajat hidupnya sebagaimana diamanahkan dalam pembukaan Undang-Undang Dasar Negara Tahun 1945. Agar Negara hadir dalam mewujudkan hal tersebut di atas, diperlukan akuntabilitas kinerja pelayanan pemerintah daerah yang berorientasi pada pemeruhan harapan dan atau keinginan rakyat selaku penerima layanan yang diselenggarakan oleh aparatur pemerintah daerah.

Pola hubungan aparatur/birokrasi dengan kecenderungan sikap mereka terhadap "clients" atau masyarakat dan kelompok dapat dibedakan dalam dua kategori yaitu: "service orientation" dan "social control orientation". Birokrasi dengan "service orientation" memberikan pelayanan dengan orang-orang yang berhubungan dengannya, dengan sikap pelayanan yang profesional yang bertujuan menjamin kepuasan pihak yang dilayani. Sedangkan birokrasi dengan "social control orientation" lebih menekankan pada pengendalian atau pengawasan karena ia menjalankan suatu peraturan guna memelihara ketertiban masyarakat.

Aparatur merupakan suatu komunitas individu-individu yang memiliki tugas dan fungsi yang terlembagakan untuk melayani rakyat diartikan secara singkat sebagai pemikir, perencana, pelaksana sekaligus pengawas jalannya kegiatan pemerintahan, pembangunan dan pembinaan masyarakat atas nama kepala daerah (Sarundajang, 2002:164). Dalam konteks pemerintahan yang baik, salah satu kunci sukses terpenting dari adanya perubahan dalam proses governance terletak pada individu-individu yang ada di dalam proses governance itu sendiri. Individuindividu adalah mereka yang menciptakan dan memelihara perubahan. Wilson dan Rosenfeld mengemukakan 4 (empat) alasan resistensi individu terhadap perubahan yaitu: kepentingan pribadi, rendahnya tingkat kepercayaan, perbedaan pandangan/penilaian, rendahnya toleransi terhadap perubahan (Sumarto, 2004:11).

Aparatur yang baik adalah yang mampu memberi kepada masyarakat apa yang mereka butuhkan, bahkan sebelum masyarakat itu sendiri memintanya. Dalam keadaan seperti ini, hati nurani aparatur pemerintahan adalah hati nurani dari masyarakat itu sendiri (Sarundajang, 2002: 164). Aparatur pemerintah Pusat maupun Daerah harus mengubah posisi dan peran dalam memberikan pelayanan publik yaitu:

1. Dari yang suka mengatur dan memerintah berubah menjadi suka melayani;

2. Dari yang suka menggunakan pendekatan kekuasaan berubah menjadi suka menolong menuju ke arah yang fleksibel, kolaburatis dan dialogis; 
3. Dari cara-cara yang sloganis menuju cara-cara kerja yang realistis pragmatis (Widodo, 2001:32).

Birokrasi merupakan suatu organisasi pemerintahan yang terdiri dari sub-sub struktur yang memiliki hubungan satu dengan yang lain, yang memiliki fungsi, peran, dan kewenangan dalam melaksanakan pemerintahan, dalam rangka mencapai suatu visi, misi, tujuan, dan program yang telah ditetapkan. Fungsi dan peran birokrasi meliputi hal-hal sebagai berikut: (1) melaksanakan pelayanan publik; (2) pelaksana pembangunan yang profesional (merrit system); (3) perencana, pelaksanan, dan pengawas kebijakan (manajemen pemerintahan); (4) alat pemerintah untuk melayani kepentingan (abdi) masyarakat dan negara yang netral dan bukan merupakan bagian dari kekuatan atau mesin politik (netralitas birokrasi).

Birokrasi yang ideal adalah birokrasi yang mampu memelihara dan meningkatkan kinerja produktif sehingga dapat memberikan pelayanan terbaik bagi masyarakat. Langkah konkret dan utama yang dibutuhkan itu, menurutnya, adalah mendorong semangat kerja di lingkungan birokrasi dan meningkatkan kapasitas aparatur birokrasi agar memiliki pengetahuan manajemen pemerintahan yang memadai serta memiliki performance yang andal, karena dalam keseharian saat ini birokrasi cenderung dipersepsikan dalam makna yang kurang bagus karena identik dengan prosedur yang berbelit-belit, tidak efisien, lamban, menghambat, mengisap, korup, dan sebagainya. Struktur dan orientasi birokrasi demikian merupakan implikasi dari penerapan prinsip-prinsip model birokrasi rasional versi Max Weber.

Bahwa pelaksanaan tugas-tugas umum pemerintahan yang good government oleh aparatur Pemerintah Daerah, khususnya di Daerah Kabupaten Labuhanbatu Selatan, dapat dilihat pada; antara lain, kualitas penyelenggaraan pelayanan publik kepada masyarakat yang merupakan hasil dari Penataan Kelembagaan Daerah sebagaimana diamanahkan dalam UndangUndang Nomor 23 Tahun 2014 Tentang Pemerintahan Daerah yang ditindaklanjuti sesuai Peraturan Pemerintah No. 18 Tahun 2016 Tentang Oraganisasi Perangkat Daerah.

Bahwa pengembangan kapasitas Pemerintahan Daerah yang dilakukan melalui penataan Kelembagaan organisasional pada Daerah Otonom Kabupaten Labuhanbatu Selatan, dimaksudkan agar mempunyai kemampuan untuk mewujudkan kesejahteraan dan kemandirian masyarakat yang merupakan salahsatu wujud dari amanah reformasi pemerintahan daerah yang mengetengahkan akuntabilitas kinerja pelayanan publik. 
Agar pelayanan yang berkualitas Pemerintah Daerah Kabupaten Labuhanbatu Selatan yang diberikan kepada masyarakat berkualitas, maka salah satu tahapan dalam administrasi pemerintahan adalah dengan melakukan penataan diberbagai fokus, seperti; (1) fokus pada kelembagaan institusi pelayanan publik yang merupakan bahagian yang tidak terpisahkan dalam satuan kerja perngkat daerah, (2) fokus pada tugas dan fungsi pelayanan kepada masyarakat selaku warga negara, (3) fokus pada sumber daya manusia aparatur pelayanan yang profesional, (4) fokus pada kualitas pelayanan yang diberikan kepada masyarakat.

Agar Pemerintah Daerah Otonom Kabupaten Labuhanbatu Selatan dapat mewujudkan kesejahteraan masyarakat melalui pelayanan yang berkualitas, maka diperlukan; (1) penataan institusi pelayanan publik, (2) tugas dan fungsi institusi pelayanan publik yang merupakan bagian dari Organsasi Perangkat Daerah, (3) peningkatan Sumber Daya Manusia Aparatur Pemerintah Daerah, dan profesionalisme aparatur dalam penyelenggaraan pelayanan publik. Citra penyelenggara pemerintahan yang selama ini terkena erosi kepercayaan masyarakat di Kabupaten Labuhanbatu Selatan, perlu diharmonisasikan antara pencitraan pemerintah daerah kaitannya dengan politik dan publik melalui perencanaan partisipatif, dengan metode, teknik, dan keterampilan dalam menyelenggarakan pelayanan publik yang berkualitas kepada masyarakat sebagaimana dalam fungsi pemerintahan daerah seperti; mengatur, memberdayakan, melayani, serta membangun, perlu diwujudkan sesuai harapan dan atau keinginan masyarakat yang ditegaskan dalam Pembukaan UUD 1945.

Salah satu bentuk akuntabilitas kinerja pelayanan publik pemerintahan Kabupaten Labuhanbatu Selatan adalah penataan kelembagaan citra penyelenggara pemerintahan yang selama ini terkena erosi kepercayaan masyarakat di Kabupaten Labuhanbatu Selatan, perlu diharmonisasikan antara pencitraan pemerintah daerah kaitannya dengan politik dan publik melalui perencanaan partisipatif, dengan metode, teknik, dan keterampilan dalam menyelenggarakan pelayanan publik yang berkualitas kepada masyarakat sebagaimana dalam fungsi pemerintahan daerah seperti; mengatur, memberdayakan, melayani, serta membangun, perlu diwujudkan sesuai harapan dan atau keinginan masyarakat yang ditegaskan dalam Pembukaan Undang-Undang Dasar Negara Republik Indonesia Tahun 1945. Bahwa salah satu bentuk akuntabilitas kinerja pelayanan publik pemerintahan Kabupaten Labuhanbatu Selatan adalah penataan kelembagaan pelayanan publik yang teridir dari; penataan Organisasi pelayanan publik, Penataan Tugas dan Fungsi, Penataan SDM Aparatur, dimaksudkan untuk mewujudkan 
penyelenggaraan pelayanan public yang tidak hanya "good government", tetapi juga "good and clean governance” dalam penyelenggaraan pelayanan publik.

\section{B. METODE}

Dalam penelitian ini peneliti menggunakan pendekatan penelitian kualitatif. Penelitian kualitatif menurut Lincoln dan Guba (1985) disebut sebagai metode yang naturalistik. Melalui pendekatan kualitatif, peneliti menemukan dan mendeskripsikan suatu fenomena yang memiliki karakter unik yang terkait dengan kinerja pemerintah daerah terhadap penyelenggaraan pelayanan publik di Kabupaten Labuhanbatu Selatan. Alasan digunakannya metode penelitian kualitatif dalam penelitian ini karena dipandang tepat dan terdapat kesesuaian antara karakteristik penelitian kualitatif dengan fenomena yang diteliti.

Dalam Penelitian ini, peneliti menggunakan penelitian deskriptif, dimana hanya terbatas pada penggambaran suatu fenomena atau obyek sebagaimana adanya, tanpa suatu maksud mengambil kesimpulan yang berlaku secara umum. Selain itu, alasan menggunakan jenis penelitian kualitatif deskriptif, dikarenakan penelitian ini bertujuan untuk menangkap berbagai fenomena informasi, khususnya yang berkaitan dengan fokus penelitian, selain itu, pendekatan ini dapat menyajikan bentuk yang holistik atau menyeluruh dalam menganalisis suatu fenomena sosial yang ada di Daerah Otonom Kabulaten Labuhanbatu Selatan.

\section{HASIL DAN PEMBAHASAN}

Pelaksanaan akuntabilitas pemerintah daerah menjadi sangat penting guna meningkatkan Tata kelola organisasi pemerintah daerah yang sesuai harapan masyarakat. (Broadbent \& Laughlin, 2005) menyebutkan bahwa pelaksanaan tata kelola organisasi sektor publik lebih banyak mengedepankan akuntabilitas managerial yang kurang mengedepankan harapan dari masyarakat sebagai prinsipal. Akuntabilitas demikian perlu dibarengi dengan bentuk akuntabilitas publik yaitu akuntabilitas yang lebih mengedepankan harapan dari pihak masyarakat. Membangun akuntabilitas public ini dalam organisasi pemerintah daerah sangat tepat karena juga menjadi tolak ukur dari apa yang dijanjikan oleh pemeritnah daerah sebelum mereka memimpin untuk diwujudkan dalam aktivitas organisasi. Dengan demikian kontrak leElimasi yang disampikan dalam bentuk visi, misi dan program kerja ketika meminta dukungan masyarakat dapat dicapai dan diterima baik oleh masyarakat sebagai prinsipal. 
Berbagai defenisi mengenai akuntabilitas dijelaskan oleh beberapa penulis antara lain oleh (Sinclair, 1995) yang mendefenisikan sebagai perilaku individu atau organisasi untuk menjelaskan dan bertanggungjawab atas tindakan mereka melalui pemberian alasan mengapa tindakan tersebut dilakukan. Definisi ini membawa konsekuensi bahwa setiap individu atau organisasi wajib menyampaikan pertanggungjawaban sebagai wujud akuntabilitas individu atau organisasi. Konsep ini mengingatkan setiap individu atau organisasi akan pentingnya akuntabilitas dibangun guna meningkatkan kepercayaan dan keberterimaan satu sama lain dalam organisasi atau organisasi dengan organisasi dalam komunitas yang lebih luas.

Akuntabilitas yang lain dipahami oleh (Gray, B., \& David, 2006) sebagai hak suatu masyarakat yang timbul karena adanya hubungan antara organisasi dan masyarakat. Pengertian ini mengangkat akuntabilitas pada tingkat yang lebih luas bahwa akuntabilitas bukan hanya milik individu atau organisasi saja tetapi menjadi hak dan milik masyarakat umum yang mempunyai keterkaitan atau keterpautan dengan individu atau organisasi tersebut. Lebih lanjut (Gray, B., \& David, 2006) menyatakan konsep akuntabilitas ini berada dalam kerangka tanggung jawab sosial yang harus dipenuhi sebagai bagian dari komunitas masyarakat luas.

Pandangan (Sinclair, 1995) dan (Gray, B., \& David, 2006) menunjukkan akuntabilitas harus disiapkan oleh subyek yang melakukan suatu aktivitas kepadapublic agar individu atau organisasi mendapat kepercayaan publik atau pihak-pihak yang mempunyai hubungan dengan organisasi yang bersangkutan. Akuntabilitas juga berhubungan dengan konsep kejujuran dan etika (Parker \& Gould, 2000). Refleksi ini menunjukkan bahwa akuntabilitas juga menyentuh aspek aspek nurani setiap individu yakni tidak hanya menjalankan ritual-ritual belaka tetapi muncul ke permukaan sebagai hasil dari proses perenungan. Dengan melibatkan hati nurani yang mendalam, maka setiap individu atau organisasi akan menjunjung tinggi nilai-nilai kejujuran dan etika yang menjadi anggukan universal untuk diperjuangkan dan diwujudkan dalam aktivitas setiap individu atau organisasi.

Ijri (1983) dan Steward (1984) dalam (Parker \& Gould, 2000) menyatakan akuntabilitas adalah komitmen dua pihak yaitu accountor (pembuat) dan accountee (penerima). Sebagai contoh dalam penyaluran dana bantuan, ada komitmen dari donatur untuk memberikan dana hanya jika dibarengi oleh komitmen dari penerima donasi untuk melaksanakan apa yang dijanjikan kepada pemberi dana. 
Dalam tataran aksiologi akuntabilitas sebagai suatu konsep ilmu pengetahuan membutuhkan praktik yang nyata. Untuk sampai pada tataran aksiologi tersebut akuntabilitas kemudian dibangun dalam kerangka ilmu pengetahuan yaitu akuntansi. Hal ini dikemukakan oleh Patton (1992) bahwa akuntabilitas dilaksanakan lewat fungsi pelaporan dimana akuntansi sebagai implementasi atau justifikasi dari tindakan individu atau organisasi. Akuntansi kemudian menjadi jembatan factual akuntabilitas yang dapat difahami secara rasional dan verfikabel guna menentukan kualitas akuntabilitas.

Perumusan akuntabilitas menjadi suatu konsep teori dalam bidang akuntansi kemudian dilakukan lewat teori stakeholder dan teori agensi. Pemikiran akuntabilitas tidak hanya penting secara moral dan teoritis namun juga secara praktik. Perjanjian akan disepakati dengan pihak lain jika agen bertindak sesuai dengan perjanjian yang ditetapkan. Komitmen untuk menjalankan perjanjian yang telah disepakati sering tidak dilakukan sehingga beberapa literatur dalam bidang akuntansi yang diangkat menjadi dalil atau teori menyatakan bahwa hubungan kedua pihak ini sering asimetris (Brown \& Moore, 2001). Teori agensi (Jensen \& Mackling, 1976) dipusatkan pada bagaimana pihak prinsipal mengelola agen agar akuntabel untuk memenuhi tujuan prinsipal. Asumsi normatif dalam formulasi ini menginginkan agar agen lebih jujur kepada prinsipal. Ancaman yang dihadapi prinsipal adalah adanya ketidakjujuran agen dan inefisiensi sehingga perlu ditopang skema insentif atau bonus untuk memotivasi agen mencapai tujuan yang diinginkan prinsipal.

Akuntabilitas juga perlu mengindentifikasi kepentingan stakeholder (Ebrahim, 2003) dan (Unerman \& O'Dwyer, 2006). Informasi menjadi bagian dari akuntabilitas yang dibutuhkan oleh stakeholder yang terlibat dalam kegiatan individu atau organisasi. Secara teoritis, seluruh stakeholder yang terlibat memiliki hak atas tanggung jawab aktivitas organisasi (Unerman \& O'Dwyer, 2006). Individu (stakeholder) dapat mengklaim tanggung jawab organisasi meliputi tanggung jawab materil, moral dan etika. Individu dapat memutuskan untuk mendapatkan sesuatu yang lebih dibandingkan individu lain jika ada perbedaan jasa dan kepuasan yang diberikan atau diterima.

Alternatif lain ialah individu dapat meminta akuntabilitas kepada organisasi berdasarkan hukum atau kontrak yang dibuat sebelum aktivitas dilaksanakan. Dengan demikian setiap stakeholder dapat menggunakan asas prudential (kehati-hatian) atas konsekuensi yang akan diterima dari organisasi pada masa akan datang jika kontrak dilaksanakan atau tidak 
dilaksanakan. Di samping itu individu juga dapat menggunakan basis strategi judgment guna menyeimbangkan aspek moral dan hukum dalam memperoleh hak dari organisasi. Dasar-dasar tersebut digunakan oleh stakeholder untuk menekan organisasi agar memenuhi keinginan para stakeholder.

Dari konsep-konsep akuntabilitas di atas, maka dapat dibangun model akuntabilitas guna menganalisis dan memahami akuntabilitas secara mendalam. Model akuntabilitas ini didasari oleh teori agensi bahwa terdapat dua pihak yang berkepentingan dalam suatu organisasi yaitu pihak prinsipal dan pihak agen. Model akuntabilitas ini kemudian dibangun oleh Gray (1996) dalam (Saerang, 2001) yang menunjukkan ada dua arah hubungan di antara dua bagian accountee atau prinsipal dengan accountor atau agen.

Laughlin (1996) kemudian mengekstensi model akuntabilitas dari Gray (1996) tersebut seperti pada Gambar 3. Model akuntabilitas ini digunakan oleh Lughlin (1996) dalam penelitian tentang akuntabilitas dalam salah satu organisasi di Inggris. Ekstensi tersebut juga tetap menjelaskan hubungan antara prinsipal dan agen yang merupakan implikasi dari teori agensi.
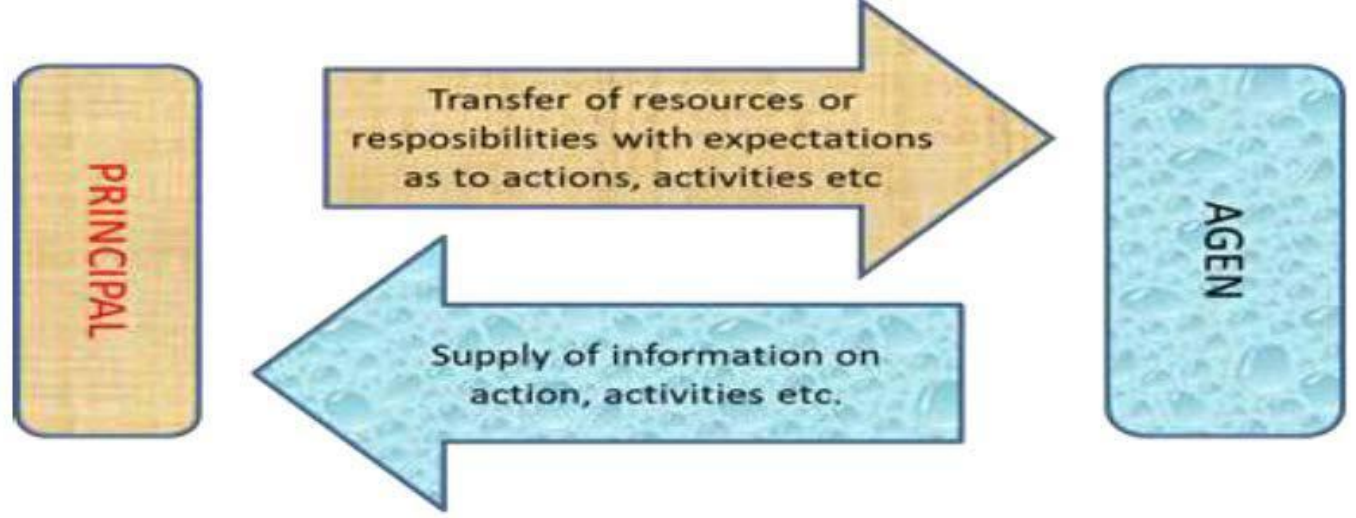

Gambar 1 Model Akuntabilitas

\section{Akuntabilitas Kejujuran dan Akuntabilitas Hukum}

Akuntabilitas kejujuran (accountability for probity) terkait dengan penghindaran penyalahgunaan jabatan (abuse of power) dan kewenangan, sedangkan akuntabilitas hukum (legal accountability) terkait dengan jaminan adanya pemahaman dan kesadaran terhadap hukum dan peraturan lain yang disyaratkan dalam penggunaan sumber dana publik.

Wewenang proses dan penandatanganan surat izin berada di satu pihak yaitu instansi pelayanan. Setiap Kantor Unit Pelayanan di tiap-tiap tingkatan memiliki kewenangan yang berbeda-beda dalam mengurus pelayanan perizinan maupun non perizinan, mulai dari tingkat 
Kabupaten, Kecamatan, sampai dengan Kelurahan. Kewenangan DPMPTSP Kabupaten Labuhanbatu Selatan telah diatur di dalam Peraturan Daerah Kabupaten Labuhanbatu Selatan Nomor 35 Tahun 2011 Tentang Organisasi dan Tata Kerja Lembaga Teknis Daerah Kabupaten Labuhanbatu Selatan menetapkan diantaranya kedudukan, tugas dan fungsi serta susunan organisasi Dinas Penanaman Modal dan Pelayanan Perizinan Terpadu Satu Pintu Kabupaten Labuhanbatu Selatan. Peneliti menemukan beberapa temuan pada indikator wewenang dan proses, antara lain :Dalam penyelenggaraan pelayanan perizinan di DPMPTSP Kabupaten Labuhanbatu Selatan ternyata masih menemukan permasalahan dimana pihak DPMPTSP Kabupaten Labuhanbatu Selatan masih harus meminta rekomendasi dan pendampingan dari SKPD terkait untuk beberapa jenis perizinan tertentu. Meski ada beberapa pelayanan perizinan yang memang sudah dapat diselesaikan dieksekusi sendiri. Namun masih ada pula jenis perizinan yang membutuhka rekomendasi dari SKPD terkait karena minimnya tenaga ahli di DPMPTSP Kabupaten Labuhanbatu Selatan.

Hambatan lain dalam Manajemen Pelayanan Terpadu Satu Pintu di Kabupaten Labuhanbatu Selatan soal akuntabilitas hukum (kewenangan dan penandatanganan perizinan) yang menyebabkan proses perjalanan berkas menjadi lama. Padahal dengan hadirnya solusi perizinan melalui Pelayanan Terpadu Satu Pintu ini, para petugas PTSP selaku pemberi pelayanan dituntut untuk memberikan pelayanan yang cepat kepada masyarakat pemohon perizinan. Namun pada kenyataannya masih banyak perizinan yang memakan waktu lama dan tidak kunjung terbit izinnya.

Sementara dari aspek akuntabilitas hokum masih ditemukan beberapa kendala mengenai koordinasi dan kurangnya pemahaman terhadap peraturan. Koordinasi di dalam hal pemberian pelayanan dan proses perizinan sangat penting untuk dilakukan. Tanpa koordinasi yang baik dari semua pihak yang terlibat didalam proses pelayanan perizinan, pelayanan tidak akan berjalan dengan efektif .Apabila setiap bagian saling bersinergi serta menjalankan fungsi dan peranannya dengan baik, tentu tujuan utama dari pelayanan yaitu kepuasan masyarakat dapat dengan mudah tercapai.

\section{Akuntabilitas Proses}

Akuntabilitas proses terkait dengan apakah prosedur yang digunakan dalam melaksanakan tugas sudah cukup baik dalam hal kecukupan sistem informasi akuntansi, sistem 
informasi manajemen dan prosedur administrasi. Akuntabilitas proses termanifestasikan melalui pemberian pelayanan publik yang cepat, responsif, dan murah biaya. Pengawasan dan pemeriksaan terhadap pelaksanaan akuntabilitas proses dapat dilakukan, misalnya dengan memeriksa ada tidaknya mark up dan pungutan-pungutan lain di luar yang ditetapkan, serta sumber-sumber inefisiensi dan pemborosan yang menyebabkan mahalnya biaya pelayanan publik dan kelambanan dalam pelayanan.

Mekanisme dan prosedur pelayanan perlu dibuat agar dapat membantu memudahkan masyarakat ketika ingin mengurus perizinan. Mekanisme dan prosedur pelayanan yang baik akan dibuat sesederhana mungkin supaya masyarakat tidak lagi banyak bertanya kepada petugas pelayanan karena sebelumnya telah memahami alur pelayanannya. Mekanisme dan prosedur pelayanan akan lebih mudah disederhanakan karena keputusannya berada di tangan Kepala DPMPTSP.

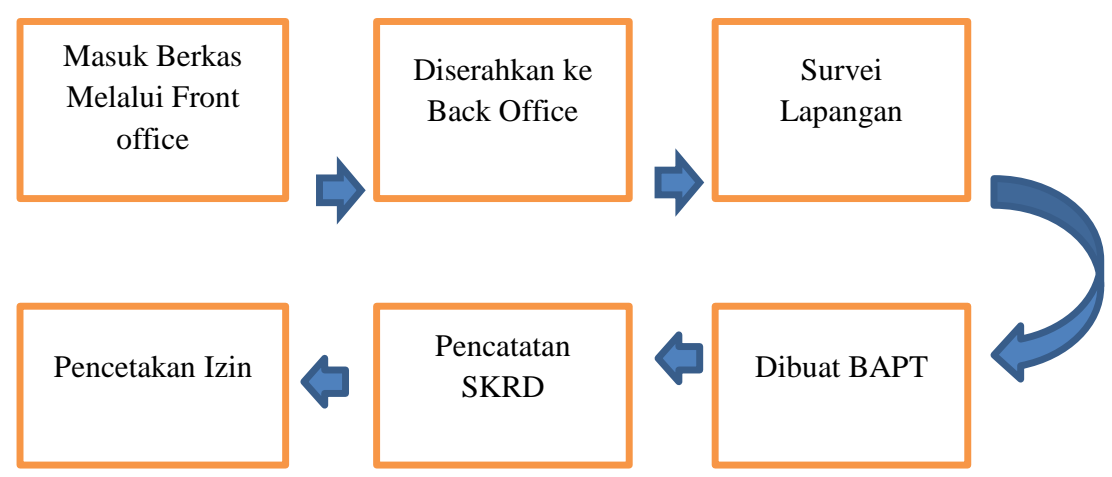

\section{Gambar 2 Mekanisme Pelayanan Perizinan di DPMPTSP Labuhanbatu Selatan}

Berdasarkan gambar di atas, dapat disimpulkan bahwa mekanisme pelayanan yang dilakukan oleh DPMPTSP Kabupaten Labuhanbatu Selatan dimulai dari masuknya berkas perizinan melalui petugas Front Office di loket pelayanan, kemudian berkas perizinan diadministrasikan ke Back Office dan diserahkan kepada petugas yang menangani izin tersebut. Selanjutnya dilakukan survei ke lapangan jika dibutuhkan, lalu akan dibuat Berita Acara Persetujuan Teknis (BAPT), setelah itu dilakukan pencatatan Surat Ketetapan Retribusi Daerah (SKRD) jika perizinan tersebut dikenakan biaya retribusi, dan terakhir pencetakan izin terbit.

Kendala yang di hadapi pihak DPMPTSP terkait masih adanya masyarakat yang menggunakan calo atau pihak ketiga dalam mengurus perizinan menjadi salah satu faktor penghambat proses terbitnya perizinan. Terlebih lagi belum ada payung hukum yang dapat digunakan untuk memberantas calo-calo tersebut. Pihak DPMPTSP Kabupaten Labuhanbatu 
Selatan telah berupaya untuk mengurangi keberadaaan calo dengan melakukan inovasi pelayanan perizinan seperti membuat antrian online. Namun ternyata inovasi ini tidak begitu disambut baik oleh masyarakat. Banyak dari mereka yang mengeluhkan rumitnya prosedur antrian online.Masyarakat beranggapan bahwa adanya antrian online ini justru mempersulit mereka di dalam mengurus perizinan, tidak lebih simpel seperti antrian manual sebelumnya. Selain itu, ternyata adanya antrian online ini masih belum menutup kemungkinan akan hadirnya calo.

\section{Akuntabilitas Program dan Keuangan}

Akuntabilitas program terkait dengan pertimbangan apakah tujuan yang ditetapkan dapat dicapai atau tidak, dan apakah telah mempertimbangkan alternatif program yang memberikan hasil yang optimal dengan biaya yang minimal.

Tabel 1. Pengukuran Kinerja

\begin{tabular}{|c|c|c|c|c|}
\hline Sasaran Strategis & Indikator Sasaran & Target & Realisasi & $\%$ \\
\hline $\begin{array}{l}\text { Terlayaninya masyarakat } \\
\text { secara menyeluruh dan } \\
\text { professional }\end{array}$ & $\begin{array}{l}\text { Lama proses perizinan (hari } \\
\text { kerja setelah berkas lengkap) }\end{array}$ & 7 Hari & 3 hari & $233 \%$ \\
\hline $\begin{array}{l}\text { Tercapainya akuntabilitas } \\
\text { pemerintah daerah }\end{array}$ & $\begin{array}{l}\text { Jumlah MoU kerjasama bidang } \\
\text { penanaman modal dan } \\
\text { investasi yang terjalin antara } \\
\text { pemerintah dan dunia usaha }\end{array}$ & $1 \mathrm{MoU}$ & $2 \mathrm{MoU}$ & $200 \%$ \\
\hline $\begin{array}{l}\text { Terwujudnya budaya } \\
\text { melayani dan mengayomi }\end{array}$ & $\begin{array}{l}\text { Terselenggaranya } \\
\text { system informasi } \\
\text { modal }\end{array}$ & 1 Sistem & 1 Sistem & $100 \%$ \\
\hline $\begin{array}{l}\text { Image pemerintahan, PNS } \\
\text { dan pelayanan } \begin{array}{r}\text { yang } \\
\text { berpihak } \\
\text { masyarakat }\end{array} \\
\end{array}$ & Jumlah investor PMA/PMDN & $9 / 45$ & 0 & $0 \%$ \\
\hline $\begin{array}{lr}\text { Meningkatnya } & \text { partisipasi } \\
\text { masyarakat } & \text { dalam } \\
\text { pembangunan } & \\
\end{array}$ & $\begin{array}{l}\text { Jumlah investor berskala } \\
\text { Nasional (PMA/PMDN) }\end{array}$ & 2 & 0 & $0 \%$ \\
\hline
\end{tabular}

Sumber: Kabupaten Labuhanbatu Selatan Tahun 2018 
ARTIKEL

Tabel 2. Rekapitulasi Retribusi Penerbitan Perizinan

\begin{tabular}{|l|l|l|l|c|}
\hline No & \multicolumn{1}{|c|}{ Uraian Izin } & \multicolumn{1}{c|}{ Target PAD } & \multicolumn{1}{c|}{ Realisasi } & Presentase \\
\hline 1 & $\begin{array}{l}\text { Retribusi 245.000.000 } \\
\text { Mendirikan Bangunan }\end{array}$ & Rp. 135.017.192 & $55.1 \%$ \\
\hline 2 & $\begin{array}{l}\text { Retribusi Izin } \\
\text { Gangguan }\end{array}$ & Rp. 200.000.000 & Rp. 0 & $0 \%$ \\
\hline 3 & Retribusi Izin Trayek & Rp. 5.000.000 & Rp. 0 & $0 \%$ \\
\hline \multicolumn{2}{|c|}{ Total } & Rp. 450.000.000 & Rp. 135.017.192 & $55.1 \%$ \\
\hline
\end{tabular}

Sumber: Kabupaten Labuhanbatu Selatan Tahun 2018

Dari beberapa temuan di lapangan dapat digambarkan bahwa akuntabilitas kinerja Dinas PMPTSP masih perlu ada peningkatan, dikarenakan Jumlah investor PMA/PMDN dan Jumlah investor berskala Nasional (PMA/PMDN) masih jauh dari harapan yakni pencapaian target $0 \%$. Kemudian dari aspek efesiensi dilihat dari semua data-data dan pencapaian sasaran program di atas bahwa Dinas Penanaman Modal dan Pelayanan Perizinan Terpadu Satu Pintu Kabupaten Labuhanbatu Selatan harus terus melakukan perbaikan sehingga target yang saat ini belum tercapai seperti pada persentase Pendapatan Asli Daerah (PAD) dari Retribusi Izin pada Tahun 2018 ini mencapai $55.1 \%$ dari target yang ingin dicapai sebesar 100\%. Oleh karena itu Dinas Penanaman Modal dan Pelayanan Perizinan Terpadu Satu Pintu (DPMPTSP) Kabupaten Labuhanbatu Selatan dapat melakukan perbaikan sehingga capaian kinerja sasaran yang telah ditargetkan dapat tercapai melebihi sebagaimana mestinya.

\section{KESIMPULAN}

Berdasarkan hasil penelitian diketahui bahwa wewenang dan proses terdiri dari apa saja dan sejauh mana kewenangan yang dapat dilaksanakan oleh DPMPTSP. Permasalahan yang terjadi adalah DPMPTSP Labuhanbatu Selatan masih harus meminta pendampingan dari peramgkat daerah teknis untuk beberapa jenis perizinan. Selain itu proses penandatanganan berkas masih manual sehingga membutuhkann waktu yang lama. Koordinasi yang dilakukan oleh DPMPTSP terdiri dari koordinasi internal dan eksternal; sering ketiadaan pegawai dan koordinasi yang masih secara manual menjadi penghambat. Mekanisme dan prosedur terkait dengan alur pelayanan, tata cara perizinan hingga persyaratan yang belum dipahami pemohon. Akhirnya beberapa pemohon memutuskan menggunakann jasa pihak ketiga (calo) yang justru semakin mempersulit pelayanan. 


\section{DAFTAR PUSTAKA}

Alderfer, H. F. (1965). Local Government in Developing Countries. New York: Mc. Graw-Hill.

Analoui, F. (2009). Reform in international institutions: the case of the United Nations. Journal of Management Development, 28(6), 495-503.

Baker, M., \& Neailley, K. (2003). From Individual Learning to Project Team Learning and Innovation: A Structured Approach. Journal of Workplace Learning, 11(2).

Dobni, C. Brooke, 2008. Measuring Innovation Culture in Organizations: The Development of a Generalized Innovation Culture Construct Using Exploratory Factor Analysis. European Journal of Innovation Management, 11(4), 539-559.

Dwiyanto, Agus. (2002) Reformasi Birokrasi Publik di Indonesia. Yogyakarta: PSKK UGM.

Fenwick, J., \& Bailey, M. (1999). Local Government Reorganisation in the UK: Decentralisation or Corporatism?. International Journal of Public Sector Management, 12(3), 249-261.

Glaser, B. G. (1992). Basic of Grounded Theory Analysis: Emergence vs Forcing. Mill Valley, CA: Sociology Press.

Hardjanto, I. (2010). Manajemen Sumber Daya Aparatur (MSDA). Malang: Fakultas Ilmu Administrasi.

Islamy, M. I. (2001). Manajemen Sumber Daya Aparatur. Fakultas Ilmu Administrasi

Kamensky, J. (1996). The Role of Reinventing Government in Federal Management Reform. Public Administration Review, 56(3).

Kulshreshtha, P. (2008). Public Sector Governance Reform: The World Bank's Framework. International Journal of Public Sector Management, 21(5), 556 - 567.

Moeleong, L. J. (2006). Metodologi Penelitian Kualitatif. Bandung: Remaja Rosdakarya.

Moenir, H. A. S. (2002). Manajemen Pelayanan Umum di Indonesia. Bandung: Bina Aksara.

Musgrave, R. A. \& Musgrave, P. B. (1991). Keuangan Negara Dalam Teori dan Praktek. Jakarta: Erlangga.

Peraturan Pemerintah Nomor 101 tahun 2000 tentang Pendidikan dan Pelatihan Jabatan bagi Pegawai Negeri Sipil.

Peraturan Pemerintah Nomor 38 Tahun 2007 tentang Pembagian Urusan Pemerintahan Antara Pemerintah, Pemerintah Daerah Propinsi, dan Pemerintah Daerah Kabupaten/Kota.

Peraturan Pemerintah Nomor 7 Tahun 2008 tentang Dekonsentrasi dan Tugas Pembantuan

Peraturan Menteri Pendayagunaan Aparatur Negara dan Reformasi Birokrasi Republik Indonesia Nomor 38 Tahun 2012 Tentang Pedoman Penilaian Kinerja Unit Pelayanan Publik.

Rondeaux, G. (2006). Modernizing Public Administration: The Impact on Organisational Identities. International Journal of Public Sector Management, 19(6), 569-584.

Rouban, L. (2008). Reform Without Doctrine: Public Management in France. International Journal of Public Sector Management, 21(2), 133-149. 
Siddiquee, N. A. (2006). Public Management Reform in Malaysia: Recent Initiatives and Experiences. International Journal of Public Sector Management, 19(4), 339-358.

Skalen, P. (2004). New Public Management Reform and the Construction of Organizational Identities. International Journal of Public Sector Management, 17(3), 251-263.

Stauss, A., \& Corbin, J. (1998). Basic of Qualitative Research: Grounded Theory Procedures and Techniques. Newbury Park, CA: Sage Publications.

Straussman, J. D., \& Mengzhong, Z. (2001). Chinese Administrative Reforms in International Perspective. International Journal of Public Sector Management, 14(5), 411-422.

Tuner, M., \& Hulme, D. (1997). Governance, Administration and Development, Making the State Work. London: Macmilan Press Ltd.

Undang-Undang Republik Indonesia Nomor 32 Tahun 2004 tentang Pemerintahan Daerah.

Undang-Undang Nomor 22 Tahun 1999 tentang pemerintahan daerah.

Undang-Undang Nomor 25 Tahun 1999 tentang Pelayanan Publik.

Undang-Undang Nomor 18 Tahun 2002 tentang Sistem Nasional Penelitian Pengembangan dan Penerapan Ilmu Pengetahuan.

Vigoda-Gadot, E. (2004). Collaborative public administration: Some lessons from the Israeli experience. Managerial Auditing Journal, 19(6), 700-711.

Zauhar, S. (1996). Reformasi Administrasi: Konsep, Dimensi, dan Strategi. Jakarta: Bumi Aksara. 